Удк 141.7:315.86

M.І.Балан, здобувач кафедри глобалістики, євроінтеграчії та управління начіональною безпекою, Начіональна академія державного управління при Президентові Украйни

DOI: 10.32702/2306-6814.2019.4.170

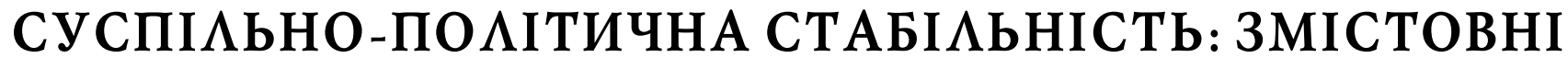

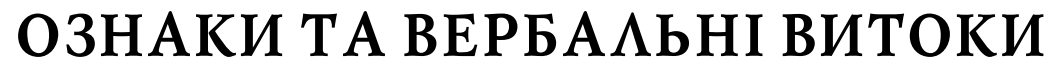

\author{
M. Balan, \\ applicant of the Department of Globalistics, European Integration and National Security, \\ National Academy of Public Administration, the President of Ukraine
}

\section{SOCIO-POLITICAL STABILITY: MEANINGFUL FEATURES AND VERBAL ORIGINS}

\begin{abstract}
Наголошено на плюралізмові інтерпретації сутності та змісту суспільної стабільності. На основі наукових підходів українських, європейських та американських науковців класифіковано прояви (типи) суспільної стабільності. Підкреслено проникнення суспільної стабільності (нестабільності як її антиподу) практично в усі сфери людського буття, об'єктивацію стабільних (нестабільних) інституцій та якостей у будь-яких часових й просторових форматах життєдіяльності соціуму, причетність практично всіх індивідів та їх об'єднань до творення або руйнування стійких, сталих, тривалих у часі (об'єднувальне слово - стабільних) соціальних інституцій.

Розглянуто множинність наукових підходів щодо визначення сутності політичної стабільності, основу якої визначає здатність владних суб'єктів до компромісу, їх ефективна спільна діяльність з метою досягнення визначених цілей розвитку. Вказано на такі формати забезпечення політичної стабільності-державну, демократичну, урядову, парламентську, легітимну, консенсусну.

Доведено природність й вербальну легкість утворення на основі сполучення прикметників "суспільний" та "політичний" складного прикметника "суспільно-політичний". Контент-аналіз наявних наукових джерел у доступних інформаційно-пошукових системах засвідчує першість "суспільно-політичного" над іншими конструкціями - "суспільно-економічним", "суспільнокультурним", "суспільно-комунікативним" тощо. Пояснено причини вивищення "суспільно-політичного" аналізу людського буття над іншими суспільно-детермінованими пізнавальними підходами на основі властивостей самої політики - її інклюзивності, універсальності, атрибутивності в усі сфери суспільного життя. На цій основі сформульовано висновок про змістовну тотожність термінів "політична стабільність"та "суспільно-політична стабільність". Аргументовано, що "політичне", виходячи з його владно позначеної природи, має підвищене наукове та практичне значення. Це практично гарантує першість суспільно-політичного аналізу над іншими підходами щодо пояснення складних соціальних пертурбацій у видимій перспективі.
\end{abstract}

The pluralism of the interpretation of the essence of social stability has been proved on the basis of the analysis of scientific approaches of Ukrainian, European and American researchers. The classification of manifestations (types) of social stability is proposed. The penetration of social stability in practically all spheres of human existence, the objectification of stable institutions and qualities in any temporal and spatial formats of society activity, the involvement of virtually all individuals and their associations to the creation or destruction of stable, sustainable, timeconsuming structures has been emphasized.

It is proved that it is expedient to make sense of social stability primarily on the basis of the David Iston system approach.

The plurality of scientific approaches to the definition of the essence of political stability, the basis of which determines the ability of the authorities to compromise, their effective joint activities to achieve the identified development goals, is proved. The following formats of political stability are indicated - state stability, democratic stability, government stability, parliamentary stability, legitimate stability, consensus stability. The key qualities of political stability are the effectiveness and consistency of power, the certainty of the order and the conditions for the adoption and 
implementation of political decisions, the legitimacy of the political system, its ability to respond adequately to internal and external changes, and to apply force (coercion) in legally defined situations.

The naturalness and verbal ease of formation on the basis of a combination of adjectives of "social" and "political" complex adjective "socio-political" is proved. Content analysis of available scientific sources in accessible information retrieval systems confirms the primacy of "socio-political" over other constructions - "socio-economic", "socio-cultural", "social and communicative".

The reasons for the superiority of the "socio-political" analysis of human existence over other social deterministic cognitive approaches are explained on the basis of the properties of the policy itself its inclusiveness, universality, attributivity. It is argued that "political", based on its powerfully designated nature, has an increased social significance. Such a status of "political" has been traced since the formation of the first primitive states, whose founders have been able to take over (to conquer) key social institutions and processes at their disposal. Over the next millennia, the dictatorship of the "political" only intensified. In the history of political thought, this tendency was marked as an ethization (governmentalization) of social relations. The extreme forms that minimized the chances of a "non-political" on independent existence, "political" acquired in the form of regimes of personal dictatorships of the Ancient World, the Middle Ages, and totalitarian regimes of the twentieth century.

The creation of democratic systems, the emergence of a culture of liberalism, the affirmation of the Institute of Human Rights and Freedoms significantly inhibited the claims of the "political" on absolute domination in society, but did not remove it from the real fabric of social relations. This practically guarantees the primacy of socio-political analysis over other approaches to explaining complex social perturbations in the visible perspective.

Ключові слова: суспільна стабільність, політична стабільність, суспільно-політична стабільність / нестабільність, політична система, політична Влада, системний аналіз.

Key words: social stability, political stability, socio-political stability / instability, political system, political power, system analysis.

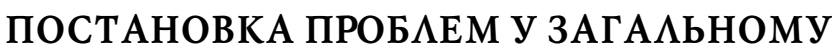 ВИГ АЯАІ}

У науково-гуманітарній літературі досить широко використовуються змістовно наближені терміни - "суспільна стабільність", "політична стабільність", "соціальна стабільність". Не менш широковживаними $є$ комбіновані словосполучення на кшталт "суспільно-політична стабільність" або "соціально-політична стабільність". Разом з тим, вважати ці вербальні конструкції синонімами, що допускають довільну взаємозаміну, аж ніяк не варто. Існують вагомі причини змістовного ототожнення суспільно-політичної стабільності насамперед 3 політичною стабільністю. Інші варіанти синонімічного використання вказаних вище термінів слід вважати невиправданими, здатними призвести до неповних або хибних результатів наукового пошуку.

\section{АНА $\Lambda$ I3 ОСТАНHIX АОС $\triangle$ IАЖЕНЬ

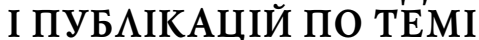

Проблематика суспільно-політичної стабільностіє предметом активного наукового аналізу у сфрері політичних, фрілософрських, юридичних, економічних наук, науки державне управління, а також соціології, психології, конфрліктології, міжнародних відносин та ін. Досить грунтовно феномен суспільно-політичної стабільності досліджено у працях В. Волинця, І. Кіянки, В. Колюха, Я. Кондратьєва, В. Лагутіна, Ю. Левенця, О. Максимової, Ю. Мацієвського, О. Руденко, М. Шаповаленко та ін. В Україні захищено низку дисертацій, присвячених різним питанням забезпечення суспільної, політичної, а також суспільно-політичної стабільності. При цьому авторами відповідних робіт активно використано наукові здобутки західних колег, що стосуються суспільнополітичної стабільності (Ф. Белі, К. Даудінга, Ф. Кімбера, Д. Яворскі, Е. Ціммермана, Д. Сірінга, А. Лійпхарта, П. Свенсона, Л. Гурвіца, К. Ейка, Р. Кімбера та ін.). Разом з тим доводиться констатувати необхідність нових досліджень з проблематики забезпечення суспільнополітичної стабільності, оскільки реальні дестабілізаційні суспільні процеси, що відбуваються в Україні та за її межами, досить часто не співпадають з існуючими підходами та вимагають оновлення відповідних теоретичних підвалин та практичних рекомендацій.

\section{ЦІАІ СТАТТІ}

Розкрити сутність і зміст "суспільної стабільності" та "політичної стабільності"; аргументувати природність утворення терміну "суспільно-політична стабільність", пояснити його сутність; виявити підстави активного використання вербальної одиниці "суспільно-політична стабільність" у науці та суспільній практиці, а також об'єктивну можливість взаємозаміни термінів "суспільна стабільність" та "суспільно-політична стабільність" на основі ключових властивостей політики - багатосуб'єктності, універсальності, інклюзивності, атрибутивності. 


\section{ВИК ААА ОСНОВНОГО МАТЕРІААУ АОС $\Lambda$ IАКЕНHЯ}

У широкому сенсі "суспільна стабільність" означає здатність організованого та раціонально структурованого людського об'єднання (включно з суспільством як великою соціальною групою) до збереження своїх інтегративних характеристик, їх розвитку, практичного застосування та передачі наступним генераціям з метою забезпечення поступального та прогресивного розвитку.

В.Лагутін з цього приводу деталізує, що "стабільність як багатоаспектне поняття з позицій інституціональної теорії передбачає збереження соціально-економічної системи, інституційного порядку і нівелювання загрози нестабільності". Стабільність суспільства, як вважає В. Лагутін, "забезпечується складним набором обмежень, які включають формальні правила, пов'язані одне з одним ієрархічними залежностями, де зміна кожного рівня ієрархії вимагає більших витрат, ніж зміна попереднього рівня". Як наслідок, "стабільне суспільство - це суспільство настільки стійке, що може нормально функціонувати протягом життя багатьох поколінь, не підриваючи власну соціально-економічну систему. Стабільне суспільство задовольняє сьогоднішн потреби, не ставлячи під загрозу можливості для задоволення потреб майбутніх поколінь" [1, с. 41]. Цей же науковець альтернативно зазначає, що це "такий динамічний стан суспільства, за якого існує усталена збалансованість інтересів соціальних груп і членів суспільства, відповідність і узгодженість між економічною, соціальною і моральною (гуманітарною, духовною) сфрерами" [2, с. 25].

3 позицій широковживаного системного підходу, застосованого О. Руденко (Україна), суспільна стабільність визначається як "упорядкована певним чином система, яка характеризується постійним динамічним розвитком, кожен з елементів якої $є$ відносно самостійним, стійким, цілісним та перебуває в ієрархічній взаємодії з іншими елементами" [3]. О. Руденко вважає, що "суспільна стабільність $€$ результатом динамічного розвитку основних підсистем суспільства (свідомісної, політичної, економічної, соціальної, культурної) в межах їх ієрархічної взаємодії, в якому відбувається трансформація стійкості, єдності та цілісності суспільства" [4, c. 14].

Варіативно суспільна стабільність може бути визначена як "керованість стану цілісності системи". Ії̈ природа визначається раціональністю та гнучкістю, тобто "адекватною реакцією на суспільні зміни, що передбачає еволюційний динамічний розвиток суспільства" [5, с. 6]. Будучи досить широкою у своїх ключових характеристиках, суспільна стабільність цілком претендує на самостійний об'єкт дослідження, предметами якого можуть бути і динамізм, і стабільність, і основні цінності системи (впорядкованість, цілісність, соціальний порядок).

О. Руденко, враховуючи суб'єкт-об'єктну складність, вертикальну ієрархічність, різномасштабність практичного втілення суспільної стабільності, пропонує класифікувати її прояви (визначити типи) на основі наступних критеріїв [3]:

за підсистемами (базовими суспільним сферами): політична, економічна, соціальна, духовно-культурна; за рівнем реалізації влади: державна, парламентська, урядова, адміністративна;

за суб'єктами управління: владно-політична, інституційна, елітарна, партійна, громадсько-політична;

за функціональним призначенням: інституціональна, нормативна, контролююча, комунікативна, інформаційна, дистрибутивна, ресурсна, моральна;

за формою прояву: внутрішня, зовнішня, змішана; за способами організації: організована, природна, стихійна;

за типом політичної влади: авторитарна, демократична, ліберальна;

за ступенем надійності: висока, середня, низька;

за масштабами: макрорівнева, мезорівнева, мікрорівнева;

за станом: повна, часткова, статична, мобілізаційна, динамічна.

Не вважаючи запропоновану класифікацію вичерпною, звернімо увагу на включення суспільної стабільності (нестабільності як її антиподу) в усі ключові сфери людського буття, об'єктивацію стабільних (нестабільних) інституцій та якостей у будь-яких часових й просторових форматах життєдіяльності соціуму, причетність практично всіх індивідів та їх об'єднань до творення (руйнування) стійких, сталих, тривалих у часі (об'єднувальне слово - стабільних) соціальних інституцій. На цих підставах соціогенезис може бути усвідомлений і як безперервне чергування, і як паралельне існування, і як асиметричний взаємовплив етапів (фаз) стабільності та дестабілізації. Від їх співвідношення залежать якісні показники конкретних суспільств, перспективи їх прогресивного або ж регресивного розвитку.

Не менший змістовний плюралізм на сторінках наукових досліджень демонструє й політична стабільність, під якою пропонується вважати "стан політичної системи суспільства, систему зв'язків між різними політичними суб'єктами, для яких характерні певна стійкість, єдність і цілісність, здатність до ефективності й конструктивності" [6, с. 631]. Ключовими якостями політичної стабільності визнаються ефективність та послідовність влади, визначеність порядку і умов прийняття та реалізації політичних рішень, легітимність політичної системи, її здатність адекватно реагувати на внутрішні й зовнішні зміни, а також застосовувати силу (примус) у законодавчо визначених ситуаціях.

І. Кіянка (Україна) розуміє політичну стабільність як "сукупність інституціолізованих структур, які здатні корегувати політичний процес як внутрішньо, так і ззовні" [7, с. 13]. Дослідниця будує таку типологію фрорматів забезпечення політичної стабільності: державна стабілізація, що сприяє її утриманню в межах політичної системи (праці Ф. Белі, К. Даудінга, Ф. Кімбера), демократична стабільність (Д. Яворскі), урядова стабільність щодо владних структур (Е. Ціммерман), легітимна стабільність (Д. Сірінг), консенсусна стабільність (А. Степан, А. Лійпхарт). Як наголошує ця дослідниця, "політична стабільність визначається не тільки сукупністю зв'язків між різними політичними суб'єктами, які здатні цілісно і конструктивно співпрацювати між собою, але й володіє можливістю балансувати конфліктну ситуацію в соціумі, а також містить у політичній системі механізми, які здатні коригувати легітимацію процесу 
політичної системи і виступати гарантом досягнення цілісності елементів самої системи".

Політична стабільність досить часто розглядається в контексті стабільності держави, оскільки держава була й залишається основним елементом політичної системи суспільства, невід'ємною умовою організації політичного процесу на системних засадах. Зокрема Я. Кондратьєв (Україна), вважає, що стабільність держави у широкому сенсі означає довгострокову здатність державних органів "приймати рішення та забезпечувати дотримання їх без відкритого застосування сили, що значною мірою залежить від законності та ефективності влади" [8, с. 986]. Державна стабільність у демократичних суспільствах базується насамперед на раціональноправових засадах. У такий спосіб досягається інституціональна легітимність влади, заснована на довірі громадян до державного устрою, державних інституцій, а не до окремих керівників.

Проблематика політичної стабільності як антитези дестабілізації досить детально розглянута у монографрічному дослідження Ю. Мацієвського (Україна) "У пастці гібридності: зигзаги трансформацій політичного режиму в Україні (1991-2014)". Зокрема Ю. Мацієвський систематизує наступні бачення політичної стабільності, авторство яких належить західним дослідникам [9, с. 401-402]:

П. Свенсон (Данія): це поняття залишається розмитим, різні дослідники використовують його стосовно різних об'єктів та властивостей цих об'єктів;

Л. Гурвіц (США): існує щонайменше п'ять підходів щодо розуміння політичної стабільності: відсутність насилля, тривалість існування уряду (владних структур), наявність легітимного конституційного режиму, відсутність структурних змін, стабільність як сукупна соціальна характеристика. Сам автор схиляється до розуміння політичної стабільності як до "системної стабільності", вимірювання якої можливе через сукупні макропоказники - суспільний добробут, рівень економічного зростання, накопичувальна та розподільна здатність уряду та ін.;

К. Ейк (США): політична стабільність $є$ регулярністю потоку політичних взаємодій, які відштовхуються від політичних ролей учасників політичного процесу та визначають інтенсивність політичних обмінів. Іншими словами, політична стабільність має потужний суб'єктивний підтекст та не може набувати уніфікованого вигляду, що підходить будь-якій країні;

К. Даудінг іР. Кімбер (США): політична стабільність це стан, за якого певний політичний суб'єкт здатний запобігати загрозливим випадковостям, що можуть спричинити вимушене невиживання, тобто вимушену зміну одного чи більше критеріїв його ідентичності.

Як узагальнення, Ю. Мацієвський пропонує перелік найбільш поширених ознак політичної стабільності [9, с. 402]: 1) відсутність насилля (мається на увазі - і всередині країни, і за її межами за участю представників цієї країни); 2) тривале існування уряду (інститутів влади); 3) наявність легітимного конституційного (політичного) режиму; 4) відсутність структурних змін; 5) регулярність потоку політичних взаємодій; 6) сукупність макропоказників (насамперед економічних - М. Б.), що свідчать про сталий розвиток суспільства.
Показники 1, 4-6 вважаються макропоказниками, що вказують на стабільність політичної системи, а 2, 3 - мікропоказниками, які стосуються окремих елементів системи. Відповідно, операціоналізація цих показників (надання числових значень) з метою вироблення універсальної фрормули політичної стабільності $є$ неможливою.

О. Максимова (Україна) виокремлює показники політичної стабільності, безпосередньо пов'язані з якістю політичної системи, яка й продукує стан стабільності політичних та ін. інститутів. На її думку, політична стабільність являє собою стан політичної системи, який характеризується єдністюїї протилежних характеристик - стійкості та мінливості. Подібна єдність - надзвичайно складна за своєю природою - досягається одночасним існуванням від'ємного зворотного зв'язку (забезпечує стабільно-лінійний перебіг суспільно-політичних процесів) та додатного зворотного зв'язку (стимулює розгортання нелінійних процесів) [10, с. $507-$ 508].

Подібне бачення проблеми грунтується на кількох базових теоретичних платорормах. Насамперед, на основі системної теорії політики Д. Істона (США), відповідно до якої політична стабільність ототожнюється з рівновагою політичної системи, яка досягається шляхом узгодження її "входу" і "виходу" та безпосередньо пов'язується з рівнем підтримки з боку широких верств населення.

Враховуються не менш важливі пояснення Е. Дафрфа і Д. Маккаманта (США): аналіз політичної стабільності вимагає використання даних про ставлення населення до політичного процесу та внутрішні резерви самої політичної системи. Як наслідок, критеріями політичної стабільності виступають: превалювання соціальної допомоги над соціальною мобілізацією; високі темпи економічного розвитку; рівномірний розподіл доходів, обумовлений серед іншого здатністю влади збирати податки; поширення інституціалізованих політичних партій із широким членством, що забезпечують залучення громадян до політичного життя.

Так само важливоює концепція демократичної політичної стабільності С. Ліпсета (США). Чинниками її забезпечення у даному разі є наявність значної частки середнього класу у загальній стратифрікації населення, консенсус основних політичних сил щодо базових цінностей і правил гри, відсутність у політичній системі антисистемних партій тощо. Відтак демократична політична стабільність забезпечується певним (доступним для більшості населення) рівнем освіти, охорони здоров'я, відповідними економічними та урбанізаційними показниками. Відсутність достатнього рівня соціальноекономічного розвитку ключових суспільних сфер оцінюється як відсутність демократії, а отже, й стабільності.

Інше, проте не менш продуктивне трактування політичної стабільності, наводить Ф. Білі (Великобританія). Остання, на його погляд, пов'язується з рівнем легітимності політичного режиму. Порушення стабільності системи виникає в умовах кризи легітимності режиму, яка виявляється в нездатності органів влади здійснювати свої функції або ж у присутності в політичному просторі країни нелегітимного насильства.

Більш вузьке (владно-виконавче) розуміння проблеми забезпечення стабільності належить Е. Ціммерману 
(Німеччина). Політична стабільність інтерпретується як функціонування одного складу легітимного уряду протягом деякого (бажано тривалого) часу, а також як уміння уряду адаптуватися до мінливих реалій. Урядова стабільність, виступаючи базисом політичної стабільності, у свою чергу залежить від типу урядового кабінету, особливостей партій, що фрормують уряд та перебувають в опозиції, традицій комплектування виконавчої влади, її здатності накопичувати практичні позитиви діяльності тощо.

Виходячи з розглянутих вище наукових шкіл, О. Максимова мінімальними умовами забезпечення політичної стабільності вважає здатність політичної системи виконувати власні функції (набувати легітимності, попереджати нелегітимне насильство, підтримувати конституційний лад тощо), а також забезпечувати баланс базових внутрішніх підсистем - інституційної, нормативнорегулятивної, функціональної, комунікативної та ін.

Деякі дослідники феномен політичної стабільності виводять з факту багаточисельності легітимних політичних суб'єктів. Так, В. Колюх (Україна) зазначає, що "в системі вищих органів сучасної демократичної держави, основними з яких є глава держави, парламент, уряд, вищі суди, політична стабільність виявляється як стан рівноваги (баланс) їхніх конституційних повноважень та їх ефективне здійснення. Відповідно, політична нестабільність виявляється як порушення балансу повноважень і функціональності вищих органів держави" [11, с. 6]. Сутнісними рисами цієї теоретичної платорорми виступають рівновага та функціональність системи суб'єктів політики як їх головні якісні характеристики. Додамо, що політична нестабільність $€$ результатом діяльності не лише легітимних, а й нелегітимних політичних суб'єктів, які існують практично в усіх країнах. Доволі часто дестабілізація політичної системи здійснюється насамперед за рахунок впливу внутрішніх та зовнішніх нелегітимних сил, на що потрібно вказувати більш акцентовано.

В. Волинець (Україна), грунтуючись на підходах С. Ліпсета, додає до бачення політичної стабільності нові аргументи. Насамперед "політична стабільність $€$ результатом оцінки двох процесів. Першим з них $є$ оцінка ефективності публічної влади. Під ефективністю маються на увазі реальні дії публічної влади, а також ті засоби, якими вона здатна реалізувати покладені на неї фрункції. Іншим процесом є легітимація. Її сенс полягає в тому, що публічна влада повинна бути здатною породжувати та підтримувати віру в те, що існуючі політичні інститути $€$ найбільш адекватними для кожної конкретної політичної системи" [12, с. 12]. Обидва аспекти політичної стабільності тісно пов'язані між собою та містять як раціонально-логічні, так й емоційно-алогічні компоненти.

Доречно узагальнити, що проблематика як суспільної, так і політичної стабільності є темою численних наукових студій як в Україні, так і за кордоном. У багатьох роботах йдеться про похідні від політичної стабільності, проте не менш важливі предмети - урядову стабільність, парламентську стабільність, етнонаціональну стабільність, міжконфесійну стабільність, стабільність партійних систем, зовнішньополітичну стабільність тощо. Винятків практично не існує: будь- яка сучасна країна змушена опікуватися проблематикою стабільності, оскільки відсутність останньої (й навіть її недостатній рівень) розглядаються у якості прямої загрози державному існуванню.

Необхідно відповісти на питання щодо співвідношення розглянутих вище термінів "суспільна стабільність" та "політична стабільність". Насамперед, важливо вказати на природність й навіть вербальну легкість утворення на основі сполучення прикметників "суспільний (-a) (-е)" та "політичний (-a) (-e)" більш складного прикметника "суспільно-політичний (-a) (-е)". Сучасні науково-інформаційні ресурси пропонують не менш важливі утворення на кшталт "суспільно-економічний", "суспільно-культурний", "суспільно-комунікативний", "суспільно-безпечний" тощо. Разом з тим, контентаналіз наявних наукових джерел у доступних пошукових системах засвідчує першість "суспільно-політичного" над іншими подібними конструкціями. Причину вивищення "суспільно-політичного" аналізу людського буття над іншими суспільно-детермінованими пізнавальними підходами доцільно пояснити на основі властивостей самої політики, змістовні ознаки якої різні автори пояснюють у дещо відмінний спосіб.

Так, Л. Елісон (Великобританія), враховуючи "природний" (історично, економічно, природно, психологічно зумовлений) стан суспільства як взаємну боротьбу індивідів та їхніх об'єднань, вказує, що "політика може існувати тільки серед людей, ... які можуть спілкуватися символічно, а отже, робити заяви, покликатися на принципи, щось доводити і сперечатися. Політика існує там, де люди не доходять згоди щодо слушності аргументів і мають принаймні деякі процедури для розв'язку своєї незгоди" [13, с. 516]. Іншими словами, політика - це комунікативний код, відсутність якого своїм наслідком матиме нездатність суспільних суб'єктів домовлятися та взаємодіяти.

Як вважає Ю. Левенець (Україна), надзвичайно важливе місце політики у соціальних відносинах пояснюється низкою чинників, властивих насамперед їй: багатосуб'єктністю, одночасною участю у політичному житті значної кількості учасників; невпинним продукуванням конкурентних (конфліктних) фрорм відносин між акторами соціального дійства на основі різноспрямованих інтересів і цінностей; ототожненням держави з результатом та вищим рівнем політичної взаємодії сторін, можливості та ресурси якої "варті, щоб за них змагатися"; виокремленням класу професійних політиків, що борються за владу, опираючись на різні соціальні платформи; пропозицією широких комунікативних форматів індивідуального та групового спілкування, побудованого на осмисленні владних процесів; здатністю конструювати різні соціальні реальності, що задовольняють (не задовольняють) замовників владних перетворень; наявністю семіотичних механізмів (матриць інтерпретації явищ і процесів суспільного життя з точки зору владних впливів); чітко позначеною нормативністю, правовою унормованістю політичних дій, яка постійно заперечується намаганнями політичних суб'єктів вийти за межі нормативного поля; пропозицією широкого спектру суспільних ролей, включно з їх девіантними або екстремістськими формами [14, с. 567-568]. 
На погляд Ю. Левенця, особливий статус "політичного" у суспільному житті додатково відтінюється іï функціями, яких жоден інший різновид упорядкованої діяльності не має. Це: раціоналізація конфліктів, недопущення силових сценаріїв розв'язання соціальних суперечностей; прийнятний розподіл і перерозподіл суспільних благ з врахуванням цінностей, інтересів, статусних та рольових показників задіяних акторів; управління суспільними процесами, регулювання соціального поля, розміщення політичних (владних) маркерів, визначення векторів та темпів руху соціуму; соціалізація особистості, залучення людини до складно організованих владних структур, визначення межії свободи / несвободи; визначення та регулювання форматів участі суспільства у вирішення внутрішніх та зовнішніх проблем розвитку [15, с. 476].

Ю. Розенфельд (Україна) підтримує функціональний підхід щодо пояснення "політичного" як превалюючого "спільного знаменника" у процесі вироблення спільних позицій. Задля цього він виводить наступні його функції: вираз (артикуляція) та реалізація значущих інтересів суспільних груп і прошарків; надання міжгруповим відносинам цивілізованого характеру, здатного примирити протиборчі сторони; розподіл (перерозподіл) матеріальних і духовних благ із урахуванням значущості соціальних груп та їх внеску в життєдіяльність всього суспільства; інтеграція суспільства та забезпечення цілісності суспільної системи; соціалізація особи, включення її в життя держави і суспільства; створення особливих фрорм спілкування між групами населення, які конфрліктують з приводу влади (використання ЗМІ, політичної реклами, засобів пропаганди й агітації тощо). В основі політичного мислення та позиціонування можуть бути як співпраця, кооперація та взаємодопомога, так і конфрронтація, насильство, ворожнеча [16, с. 288].

Л. Герасіна (Україна) узагальнює, що політика - це "сорера суспільних відносин (організаційного, регулятивного і контрольного характеру), в якій здійснюються здобуття та реалізація влади, збалансування соціальних інтересів, фрормування політичних інститутів, прийняття і виконання владних рішень". Виходячи з цього, головними властивостями політики, які підкреслюють ї̈ всеохоплюючу роль у суспільному житті, $є$ універсальність (вплив на всі елементи соціуму, події та відносини в ньому), інклюзивність (здатність необмеженого проникнення у різні суспільні сфрери), а також атрибутивність (можливість сполучення з будь-якими неполітичними явищами, стосунками і процесами) [17, с. 524525].

Як видно з наведених вище аргументів авторитетних дослідників, "політичне", виходячи з його владно позначеної природи, має підвищене соціальне значення. Вірогідно, такий статус "політичного" простежується з моменту утворення перших примітивних держав, фундатори яких виявились спроможними перебрати у своє розпорядження (підкорити) ключові суспільні інститути та процеси. Впродовж наступних тисячоліть диктат "політичного" лише посилювався. В історії політичної думки ця тенденція була позначена як етатизація (одержавлення) суспільних відносин. Крайніх форм, які мінімізували шанси "неполітичного" на самостійне існування, "політичне" набуло у вигляді режимів особистих диктатур Стародавнього світу, епохи Середньовіччя, а також тоталітарних режимів XX ст. Створення демократичних систем, виникнення культури лібералізму, ствердження інституту прав і свобод людини значно загальмували претензії "політичного" на абсолютне домінування у соціумі, проте аж ніяк не вилучили його 3 реальної тканини суспільних взаємин.

\section{ВИСНОВКИ ТА ПЕРСПЕКТИВИ ПОАА ЬШИХ РОЗВІАОК}

Виходячи з властивостей політики, що мають загальносуспільний масштаб, високу проникну здатність в інші сорери, потенціал максимального охоплення громади державно-владними ініціативами, можна стверджувати про змістовну тотожність термінів "політична стабільність" та "суспільно-політична стабільність". Їх взаємозаміну (синонімізацію) слід вважати цілком доречними пізнавальними опціями, які не загрожують істинності здобутих результатів. На противагу цьому термін "соціально-політична стабільність" має певні обмеження у контексті існування різних фоорм "соціального", віддаленого від політичних впливів, а також існування "асоціальної" складової суспільного життя.

Не ставлячи під сумнів значення економічної, духовно-культурної, інфрормаційної, екологічної, науково-технологічної та ін. сорер, підкреслимо, що навіть у сучасних умовах всі вони так чи інакше залежні від якісних ознак політичного (правлячого) суб'єкта, його освітніх, громадянських, ресурсних, діяльнісних, комунікативних, навіть особистісно-персональних можливостей. Відтак винесений у назву статті термін "суспільно-політична стабільність" має триєдину конструкцію: а) будується на суспільній стабільності, потребу в якій відчуває більшість громадян, б) коригується, видозмінюється під впливом політичної стабільності, яка у свою чергу $є$ або результатом цілеспрямованої діяльності владарюючого суб'єкта, або моментом вимушеної рівноваги низки суб'єктів у боротьбі за владу, в) базується на особливому (підвищеному, домінуючому) значенні "політичного" у загальній структурі людського мислення і діяльності. Це практично гарантує першість суспільно-політичного аналізу над іншими підходами щодо пояснення складних соціальних пертурбацій у видимому майбутньому.

У перспективі корисною могла б вважатися проблематика інституційного (інструментального) забезпечення суспільно-політичної стабільності у демократичних та авторитарних країнах в умовах невпинного накопичення викликів, загроз і небезпек внутрішнього, зовнішнього та комбінованого походження, що змушує ці країни вдаватися як до звичних (історично апробованих), так і нестандартних (гібридних) способів стабілізації суспільного середовища.

\section{Література:}

1. Лагутін В.Д. Можливості інституційного аналізу суспільної стабільності та розвитку / В.Д. Лагутін // Держава та економіка. Вісник КНТЕУ. - 2018. - № 3.

2. Лагутін В.Д. Інституційна природа суспільної стабільності в Україні / В.Д. Лагутін / / Економічна теорія та право. - 2018. - № 1. 
3. Руденко О.М. Концептуальний підхід до визначення поняття "суспільна стабільність" / О.М. Руденко // [Електронний ресурс]. - Режим доступу: http:// www.dridu.dp.ua/vidavnictvo/2009/2009-02(2)/ Rudenko.pdf.

4. Руденко О.М. Теоретико-методологічні засади дослідження суспільної стабільності в науці державного управління: автореф. дис.... д-ра наук з держ. упр.: 25.00.01 / О.М. Руденко; Нац. акад. держ. упр. при Президентові України. - К., 2011. - 36 с.

5. Руденко О.М., Мединська Г.А. Сутність поняття "суспільна стабільність"у теорії публічного управління / О.М. Руденко, Г.А. Мединська / / Теорія та практика державного управління. - 2017. — № 1.

6. ШаповаленкоМ.В. Стабільність політична / М.В. Шаповаленко / / Політологічний енциклопедичний словник. Упорядник В.П. Горбатенко. - К.: Генеза, 2004. $-736 \mathrm{c}$.

7. Кіянка І.Б. Політична стабільність: суть і основні засоби її досягнення в Україні [Текст]: автореф. дис.... к. політ. н.: спец. 23.00.02 - політичні інститути і процеси / І.Б. Кіянка. - Львів, 2003. - 18 с.

8. Кондратьєв Я. Стабільність держави / Я.Кондратьєв / / Міжнародна поліцейська енциклопедія: у 10 т. / Відп. ред. Ю.І. Римаренко, Я.Ю. Кондратьєв, В.Я. Тацій, Ю.С. Шемшуценко. - К.: Видавничий дім "Ін Юре", 2003. - Т. 1. Теоретико-методологічні та концептуальні засади поліцейського права та поліцейської деонтології. -1183 c.

9. Мацієвський Ю.В. У пастці гібридності: зигзаги трансфрормацій політичного режиму в Україні (19912014): монографрія / Ю.В. Мацієвський. - Чернівці: Книги - XXI, 2016. - 552 с.

10. Максимова О. Політична стабільність / О. Максимова // Політологія: навчальний енциклопедичний словник-довідник / За наук. ред. Н.М. Хоми. - Львів: "Новий Світ - 2000", 2014. - 779 с.

11. Колюх В.В. Інституціональні чинники політичної стабільності в демократичному суспільстві: автореф. дис... канд. політ. наук: 23.00.02 / В.В. Колюх; Київ. нац. ун-т ім. Т. Шевченка. - К., 2007. - 17 с.

12. Волинець В.В. Легітимність влади як фактор політичної стабільності суспільства: автореф. дис... канд. політ. наук: 23.00.02 / В.В. Волинець; Одес. нац. юрид. акад. - О., 2008. - 19 с.

13. Елісон Л. Політика (politics) / Л. Елісон / / Короткий оксфордський політичний словник. - К.: "Основи", 2006. - 792 с.

14. Левенець Ю.А. Політика / Ю.А. Левенець // Політична енциклопедія. Редкол.: Ю. Левенець (голова), Ю. Шаповал (заст. голови) та ін. - К.: Парламентське видавництво, 2011. - 808 с.

15. Левенець Ю.А. Політика / Ю.А. Левенець // Політологія: навчальний енциклопедичний словник-довідник / За наук. ред. Н.М. Хоми. - Львів: "Новий Світ - 2000", 2014. - 779 c.

16. Розенфельд Ю. Політика / Ю. Розенфрельд / / Соціологічна енциклопедія. Укладач В.Г. Городяненко. - К.: Академвидав, 2008. - 456 с.

17. Герасіна Л.М. Політика / Л.М. Герасіна / / Політологічний енциклопедичний словник / За ред. М.П. Требіна. - Х.: Право, 2015. - 816 с.
References:

1. Lahutin, V.D. (2018), "Possibilities of institutional analysis of social stability and development", Derzhava ta ekonomika. Visnyk KNTEU, vol. 3.

2. Lahutin, V.D. (2018), "Institutional Nature of Public Stability in Ukraine", Ekonomichna teoriia ta pravo, vol. 1.

3. Rudenko, O.M. (2019), "Conceptual approach to the definition of "social stability"", available at: http:// www.dridu.dp.ua/vidavnictvo/2009/2009-02(2)/ Rudenko.pdf (Accessed 30 Jan 2019).

4. Rudenko, O.M. (2011), "Theoretical and methodological principles of research of social stability in science of public administration", Ph.D. Thesis, Public Administration, Nats. akad. derzh. upr. pry Prezydentovi Ukrainy, Kyiv, Ukraine.

5. Rudenko, O.M. and Medyns'ka, H.A. (2017), "The essence of the concept of "social stability" in the theory of public administration", Teoriia ta praktyka derzhavnoho upravlinnia. - № 1.

6. Shapovalenko, M.V. (2004), "Stability is political", Politolohichnyj entsyklopedychnyj slovnyk [Political Encyclopedic Dictionary], Heneza, Kyiv, Ukraine.

7. Kiianka, I.B. (2003), "Political stability: the essence and basic means of its achievement in Ukraine", Ph.D. Thesis, Public Administration, L'viv, Ukraine.

8. Kondrat'iev, Ya. (2003), "Stability of the state", Mizhnarodna politsejs'ka entsyklopediia: u 10 t [International Police Encyclopedia: 10 volumes], Vydavnychyj dim "In Yure", Kyiv, Ukraine.

9. Matsiievs'kyj, Yu.V. (2016), U pasttsi hibrydnosti: zyhzahy transformatsij politychnoho rezhymu $v$ Ukraini (1991-2014) [In the trap of hybridity: zigzags of the transformations of the political regime in Ukraine (19912014)], Knyhy - XXI, Chernivtsi, Ukraine.

10. Maksymova, O. (2014), "Political stability", Politolohiia: navchal'nyj entsyklopedychnyj slovnykdovidnyk [Politics: An educational encyclopedic dictionarydirectory], Novyj Svit - 2000, L'viv, Ukraine.

11. Koliukh, V.V. (2007), "Institutional factors of political stability in a democratic society", Ph.D. Thesis, Public Administration, Kyiv. nats. un-t im. T.Shevchenka, Kyiv, Ukraine.

12. Volynets', V.V. (2008), "Legitimacy of power as a factor of political stability of society", Ph.D. Thesis, Public Administration, Odes. nats. iuryd. akad., Odesa, Ukraine.

13. Elison, L. (2006), "Politics", Korotkyj oksfords'kyj politychnyj slovnyk [Short Oxford Political Dictionary], Osnovy, Kyiv, Ukraine.

14. Levenets', Yu.A. (2011), "Politics", Politychna entsyklopediia [Political Encyclopedia], Parlaments'ke vydavnytstvo, Kyiv, Ukraine.

15. Levenets', Yu.A. (2014), "Politics", Politolohiia: navchal'nyj entsyklopedychnyj slovnyk-dovidnyk [Politics: An educational encyclopedic dictionary-directory], Novyj Svit - 2000, L'viv Kyiv, Ukraine.

16. Rozenfel'd, Yu. (2008), "Politics", Sotsiolohichna entsyklopediia [Sociological Encyclopedia], Akademvydav, Kyiv, Ukraine.

17. Herasina, L.M. (2015), "Politics", Politolohichnyj entsyklopedychnyj slovnyk [Political Encyclopedic Dictionary], Pravo, Kharkiv, Ukraine.

Cтаття надійшла до редакиї 05.02.2019p. 